\title{
Foreign Policy, Islam and Democracy in Indonesia
}

\author{
Dewi Fortuna Anwar \\ Indonesian Institute of Sciences
}

\begin{abstract}
The relations between Islam and Democracy in Indonesia and their implications for the country's foreign policy have attracted considerable attention in recent years. In the early years of his first presidential term, Susilo Bambang Yudhono introduced the concept of Indonesia's international identity, that is, as a country in which Islam, democracy and modernity go hand in hand. In the post-9/11 international context, in which perceptions of Islam are largely negative, Indonesia's special attributes as the largest Muslim-majority country and the world's third largest democracy have special values. The international community, especially Western countries, has looked to Indonesia to provide an alternative face of Islam in the midst of rising religious extremism and terrorism. Indonesia, however, still faces many challenges in realising its aspirations to be a bridge between the Islamic world and the West, and as an alternative model within the Islamic world. Frequent acts of religious intolerance have marred Indonesia's claim as a moderate Islamic force while Indonesia has generally been perceived to lie in the periphery of the Islamic world.
\end{abstract}

\section{Introduction}

Since its relatively successful transition to democracy, Indonesia's political leaders in recent years have been quick to tout and capitalise on the country's credentials as the largest Muslim nation, and the world's third largest democracy that has an open, outward-looking modern society. Although Indonesia for decades has been home to the largest number of Muslims on the planet, it is only recently that this fact has gained a new saliency after being put in tandem with Indonesia's new democratic credentials, which are regarded as unique and noteworthy. This is clearly a reflection that, notwithstanding well-grounded arguments that Islam and democracy are not in conflict but actually 
support each other, democratic polities are still a rarity among Muslimmajority countries. This paper focuses on the theme of foreign policy in the context of Islam and democracy in Indonesia, and was originally presented as a keynote speech at a conference on these specific topics in New Zealand in 2006. ${ }^{1}$

The issues of 'foreign policy', 'Islam' and 'democracy' cover three very important and quite distinct subjects, each of which needs to be studied and discussed separately in its own right, which can actually be done without too much reference to the others. Nevertheless, by juxtaposing these three distinct subjects under the overarching theme of understanding Indonesia today, it is to be hoped that one sees not merely a few pieces of the vast and extremely complex Indonesian jigsaw puzzle, but also the link between the different parts. In a modest attempt to provide a coherent framework for these subjects, the writer would like to look briefly at the relations between foreign policy, Islam and democracy in Indonesia, past, present and future.

\section{Indonesia's Foreign Policy Formulation}

Foreign policy is basically an extension of domestic politics. Even though the influence of the external environment cannot be discounted, Indonesia's foreign policy has for the most part been determined by domestic priorities. ${ }^{2}$ Although the basic doctrine of Indonesia's foreign policy has remained the same, that is, to be free and active, its articulation and implementation have evolved, depending upon the political constellations, the world view of the leaders and the priorities of the government at any given time. Rizal Sukma noted in an article that, in its historical evolution, Indonesia's free and active foreign policy doctrine has manifested one of its three key components at different times,

1 An earlier version of this paper was delivered as the keynote speech at a seminar: 'Understanding Indonesia 2006: Foreign Policy, Islam and Democracy', organised by the Indonesian Embassy, the Asian Studies Institute (VUW), the Asia Forum and the Asia New Zealand Foundation. Wellington, New Zealand, 1 May 2006.

2 For a classic analysis of the domestic imperatives of Indonesian foreign policy, which examined the radical change in Indonesia's foreign policy between Soekarno and Soeharto, see Weinstein (1976). 
namely anti-colonialism, independence and pragmatism, depending on the context and needs of a particular period. Nonetheless, successive Indonesian governments have steadfastly adhered to this basic free and active foreign policy doctrine since it was first enunciated in 1948 (Sukma, 1995).

In his first major foreign policy speech in 2005, President Susilo Bambang Yudhoyono argued that an independent and active foreign policy 'entails independence of judgment' and 'freedom of action'. Yudhoyono used the metaphor of 'navigating a turbulent ocean' to describe the challenges currently faced by Indonesian foreign policy, comparing it with the metaphor used by Vice-President Hatta in 1948 to describe the challenges of the Cold War that required Indonesia's foreign policy to have the ability to 'row between two reefs'. According to Yudhoyono, Indonesia's independent and active foreign policy should have a constructive approach, prevent Indonesia from entering into military alliances and be characterised by connectivity, compelling Indonesia to have a healthy engagement with the outside world.

Equally importantly, as stated by President Yudhoyono, an independent and active foreign policy should project Indonesia's national identity: Indonesia's international identity 'must be rooted in a strong sense of who we are. We cannot be all things to all people. We must know who we are and what we believe in, and project them in our foreign policy'. President Yudhoyono went on to further define Indonesia's identity as follows: 'We are the fourth most populous nation in the world. We are home to the world's largest Muslim population. We are the world's third largest democracy. We are also a country where democracy, Islam and modernity go hand in hand'. ${ }^{3}$ This foreign policy statement by the President can be seen as part of the efforts being made to transform Indonesia's international image in line with the new national identity that is now being forged.

Throughout most of Soeharto's New Order period, Indonesia, although criticised in some quarters for being undemocratic and a violator of

3 Speech by President Susilo Bambang Yudhoyono before the Indonesian Council on World Affairs (ICWA). Jakarta, 20 May 2005. 
human rights, nevertheless enjoyed a relatively positive international image. Indonesia was regarded as an anchor for stability in Southeast Asia and a first among equals among the member states of ASEAN (Anwar, 1991). During the Cold War period, Western governments and other non-communist countries saw Indonesia as an important partner in containing international communism and particularly as a bulwark against Communist China. President Soeharto himself, as a founder of ASEAN, was viewed and treated as an elder statesman in the region. Indonesia's success in developing its economy and advancing its human resources enabled President Soeharto to reassert Indonesia's leadership position among the developing countries, such as within the NonAligned Movement (NAM) towards the later years of his rule. Indonesia was chairman of NAM in 1992-95 and was credited for transforming it from a primarily political organisation that tended to be anti-West into a more development-oriented organisation that espoused cooperation with the West. Indonesia's role within the wider Asia-Pacific region was also notable, such as its chairmanship of APEC (Asia-Pacific Economic Cooperation), which produced the Bogor Declaration of 1994, laying down the future directions of APEC.

With the onset of the economic crisis in mid-1997, however, followed by the fall of Soeharto and a period of political instability and social upheaval marked by rioting, communal conflicts, lawlessness, separatist movements and a general decline in the people's welfare, Indonesia was seen by many as in danger of becoming a failed state. The international image of Indonesia changed virtually overnight from that of a strong state with a robust economy and a key player in various regional and international forums to that of an ailing state which had great difficulties in keeping its own house in order. Far from being able to contribute to regional and international peace, Indonesia's weakness was seen as posing a problem not just to itself but also to the wider region. The Indonesian government's lack of capacity to enforce law and order and protect its territories contributed to the increase in terrorist attacks at home and pirate attacks in Indonesian waters. ${ }^{4}$ Nevertheless, although

4 Indonesia has been the target of several major terrorist attacks causing great numbers 
the difficulties faced by Indonesia were and are real, the image problems besetting the country have been even more damaging, causing it to suffer from what we may term the 'CNN effect', as graphic news of violence and conflicts are repeated over and over again, obscuring other realities.

\section{Democratic Consolidation against All Odds}

Despite the litany of bad news coming from Indonesia, there were and are, in fact, other realities. Against all odds, Indonesians succeeded in transforming the long-entrenched authoritarian political system into a more democratic system within a very short time and almost without bloodshed. Rejecting the earlier relativism of the New Order, Indonesia has now eagerly embraced universal values of human rights, including the much contested civil and political rights. ${ }^{5}$ Freedom of expression and association are recognised and protected by law, and in 2004 Indonesians elected the president and vice-president directly for the first time in the country's history, followed by the second direct presidential-vice-presidential election in 2009. All of the provincial governors, regents and mayors throughout the vast archipelago are now also elected directly. A radical decentralisation policy has been put in place to ensure more equitable relations between the central government and the regions and address regional grievances, which in certain areas had led to demands for independence. Indonesia continues to face many difficult challenges, particularly in the economic field and in the area of governance, but it is certainly not a failed or a failing state, or one that is in danger of disintegration.

There is every reason to be optimistic that Indonesia will evolve into a mature plural democracy and that, unlike in the late 1950s, when

of deaths and injuries carried out by a regional terrorist network, the Jamaah Islamiyah, believed to be associated with the global terrorist organisation, Al-Qaeda. The first major bomb attack took place in Bali in October 2002, which mostly targeted foreign tourists, in which over 200 people died, mostly Australians. Subsequent terrorist attacks using bombs occurred twice in Jakarta and another one in Bali, which again primarily targeted foreigners, though most of the victims were Indonesians.

5 The 1945 Constitution has been amended four times and it now incorporates the principles of human rights and democracy amongst its articles. 
parliamentary democracy eventually gave way to a 'guided democracy', this time democracy will be consolidated and sustained over time. In the 1950s, when Indonesia experimented with liberal democracy, the political fragmentation based on the aliran ${ }^{6}$ was still very deep and wide because at that time there was no national consensus about the ultimate ideological foundation or form of the state, while at the same time the country was wracked by regional rebellions and armed insurgencies. Sharp ideological cleavages between the secular nationalists, the Islamists and the communists, who espoused very different visions of Indonesia, made political compromises more difficult to achieve. After cabinets rose and fell in quick successions and Jakarta was unable to deal with regional grievances, many people became disillusioned with democracy and thus welcomed Soekarno's call to bury the parties and end the 50 per cent plus one democracy and replace it with the socalled 'Guided Democracy'. ${ }^{7}$ Now, it is believed that Indonesians have become more mature politically and, more important, there is already a national consensus in place regarding the foundation and form of the state, as well the existence of a vibrant civil society, so that political differences would not be so divisive as to threaten the existence of the state or jeopardise national unity. Recent controversy about the Bank Century bailout, which pitted the DPR (House of Representatives) against the government, is a case in point. Despite its heated nature and even concerns that the DPR might find wrongdoing committed by senior elements in the government that could open the way for the impeachment of the vice-president or even the president, the whole process has in general simply been seen as a democratic exercise of the DPR's role that should not cause undue alarm (Noor, 2010). The government has been able to function as normally as it could under such

6 Aliran literally means "stream". Its use here refers to religious or social identities around which Indonesian political organisations were grouped in the past so that political differences tended to be primordial in nature, such as between santri (devout Muslims) and abangan (nominal Muslims).

7 For the best analysis of why Indonesia's first democratic experiment in the immediate post-independence years was very short-lived and which later opened the way for four decades of authoritarian rule under Soekarno and Soeharto, see Feith (1962). 
conditions and the Indonesian economy has continued to grow, albeit sluggishly, given the prevailing global economic malaise.

\section{Islam and Foreign Policy in Indonesia}

The second theme of this paper is the position and role of Islam in Indonesian politics, particularly in relation to the conduct of Indonesian foreign policy. The way that Islam had spread and developed in Indonesia has undoubtedly contributed to the distinctive characteristics of Indonesian Muslims, which are quite different from those of Middle Eastern Muslims. Islam in Indonesia is generally regarded as moderate, tolerant and outward-looking. Although nearly 90 per cent of Indonesians are Muslims, Indonesia is not an Islamic state, nor is Islam the official religion of the state. To strike a compromise between those who wanted to establish an Islamic state and those who opposed it, in 1945, Pancasila was adopted as the ideology of the state. Pancasila is neither a fully secular nor a religious ideology. The first principle of Pancasila is Belief in One God, without specifying adherence to any particular religion. In recognition of Indonesia's religious pluralism, the Indonesian government currently gives recognition to five religions, namely, Islam, Roman Catholicism, Protestantism, Hinduism and Buddhism. The holidays celebrated by all of these religions are declared as national holidays. In the post-Soeharto era, recognition of a Chinese cultural identity in Indonesia has been restored and the Chinese New Year is now also celebrated as a national holiday.

The acceptance of religious, social and political pluralism by the majority of Indonesians, who are predominantly Muslim, is clearly a key to Indonesia's successful transition from authoritarianism to a pluralist democracy. It is important to note that there are now several Islamic political parties using Islam as their political platform, which under Soeharto had been forbidden, but none of these parties espouses the establishment of an Islamic state any longer. Members of the Parliament and the People's Consultative Assembly, from Islamic political parties and secular parties whose supporters are predominantly Muslims, have 
amended the Constitution and passed laws that are intended to ensure that Indonesia follows the principles of democracy characterised by checks and balances of power, popular participation and government accountability, as well as respect for human rights, with equal rights for men and women and respect for the rights of minorities.

A national consensus has been reached that, although the body of the Constitution can be amended, the preamble to the Constitution, which lays down the form and the ideological foundation of the state, must never be touched. This means that Pancasila, which promotes and protects the concept of unity in diversity as the state ideology, has been accepted as final. Moreover, Islamic organisations, including the country's two largest social organisations, Nahdhatul Ulama and Muhammadiyah, associated with traditionalist and modernist Islam respectively, have greatly contributed to Indonesia's thriving civil society, a prerequisite for a viable democracy.

Indonesia's achievements in establishing democracy, which has been an important international agenda in the post-Cold War period, have not only been a cause of pride at home, but have also attracted praise from other countries, particularly from the West. The fact that Indonesia is also the largest Muslim nation attracts special attention because there is a common assumption that Islam and democracy do not go hand in hand. A history of conflict between Christianity and Islam, especially from the time of the Crusades onward, has created mutual hostilities and suspicions between these two faiths. Converging strategic interests have led to the development of close relations between a number of Islamic countries and key Western powers, but the underlying suspicions between peoples from these two groups have remained.

Popular Western perceptions of Islam have on the whole been negative, mostly shaped by events in the Middle East. Islamic societies are often portrayed as backward, intolerant, discriminatory towards women, repressive, espousing violence including terrorism and anti-Western. Popular perceptions regarding the West in Muslim countries are also generally negative. Western countries, led by the United States, are often viewed as aggressive and rapacious, wanting to dominate the rest of 
the world and exploit other countries' resources for their own benefits, hypocritical and practising double standards, decadent and permissive, and anti-Islam. It is in this context that the social and political evolution of Indonesia, where, as President Yudhoyono said, democracy, Islam and modernity go hand in hand, has a special value. The new Indonesia would like to project these three characteristics as its new international identity, partly to counter the negative image that has dogged the country after the collapse of the New Order, as well as to help dispel some of the negative stereotypes of Islam.

In the wake of the 11 September 2001 terrorist attacks against the United States by Muslim terrorists associated with the Al-Qaeda terrorist organisation, and the subsequent US-led war against terrorism, which is widely perceived to be targeting Muslims, relations between Islam and the West have deteriorated even further. The American invasions of Afghanistan and Iraq have generated a strong anti-US sentiment in Muslim societies world-wide. Talk about the "clash of civilisations" is rampant, and mutual suspicion as well as mutual acts of stupidity have abounded, such as the fracas over the publication of the derogatory cartoons of the Prophet Muhammad that began in a small town newspaper in Denmark. ${ }^{8}$

Faced with a widening gap between Islam and the West, which has detrimental consequences for international security as a whole, a number of major Western countries are now beginning to look at Indonesia; first, as a possible alternative model for other Muslim societies, and second, as a bridge between Western countries and the rest of the Islamic world. It is, therefore, not surprising that in March and April 2006 alone Indonesia received visits from the US secretary of state, the British prime minister, the Dutch prime minister and the European Union high representative for common foreign and security policy.

8 A cartoon of the Prophet Muhammad wearing a bomb as his turban, published in a little known Danish newspaper in 2005, sparked worldwide Muslim outrage. In Islam, the Prophet is not allowed to be presented in drawings so the cartoon was regarded as deeply offensive by Muslims. The violent acts carried out by some Muslims in protesting the cartoon, however, only served to reinforce the stereotype of the violent nature of Islam in the eyes of its critics. 
Among the requests to the Indonesian government by these high-level visitors is that Indonesia play a role in helping to mediate in the conflicts in the Middle East. In subsequent years, international and Western expectations that Indonesia should act as the interlocutor for a moderate Islam have continued unabated, as evidenced from the discussions held at the Wilton Park Conference in the UK in early March 2010. As noted by Rizal Sukma (2010) who attended the conference: 'One common suggestion, especially from the international community, is for Indonesia to play a role as a global Islamic voice. It is often argued that Indonesia, as the largest Muslim-majority country in the world, should demonstrate to the world that Islam can be a 'positive' force in world affairs. Indonesia, according to this view, should demonstrate that Islam can go hand in hand with democracy'.

It is important to note, however, that the current focus on Islam as part of Indonesia's national identity, and the way it is being projected in Indonesia's foreign policy, is in fact a new development in Indonesian history, directly related to the domestic political constellations in the post-Soeharto period and to the current international environment. Despite the fact that Islam has always been the religion of most of the population of modern Indonesia, as mentioned earlier, Indonesia has not been established as an Islamic state. Yet for four decades after Indonesia's independence and acceptance of Pancasila as the ideology of the state, a number of Islamic parties and movements continued to struggle for the establishment of an Islamic state or, at the very least, for Muslims to be mandated to follow Islamic law (Sharia). Throughout the 1950s and 1960s the Indonesian military had to put down armed rebellions in Aceh, West Java and South Sulawesi that wanted to establish an Islamic state by force. Consequently, President Soekarno and President Soeharto both viewed political Islam with suspicion. Under Soeharto political Islam was strictly proscribed. Although Islam as a religion and a source of social values was allowed to flourish throughout the New Order period, official recognition of Islam as part of Indonesia's national identity was never openly articulated. ${ }^{9}$

9 There have been many books on the subject of Islam and politics in Indonesia. Among the 
Throughout most of Indonesia's history since independence, and until recently, Islam has not had much effect on Indonesia's foreign policy, except as a constraining factor on a limited number of issues. Indonesia's doctrine of a 'free and active' foreign policy, first introduced in 1948, was the response of a newly independent country to the bipolar divisions of the Cold War. Preoccupied with the struggle to complete its decolonisation from the Dutch and unwilling to subject its foreign policy to the dictates of one or the other of the super powers, Indonesia became a founder and leading member of the Non-Aligned Movement. ${ }^{10}$

Solidarity among developing countries took precedence over solidarity among Muslim countries as co-religionists per se. Indonesia's support of the Palestinian people and refusal to establish diplomatic ties with Israel until the Palestinian problem is resolved has been justified by the government not on religious grounds but on Indonesia's historical opposition to colonialism and support for self-determination. Among the Indonesian people in general, however, support for the Palestinians and opposition to Israel have mostly been because of religious sentiments. Strong public opposition to any initiatives to open links between Jakarta and Tel Aviv has been the single most important manifestation of the Islamic constraint to Indonesia's foreign policy. Because the Palestinian issue has continued to dominate Middle Eastern politics for decades, and the United States has consistently been seen as biased in favour of Israel, a number of Islamic groups in Indonesia have also viewed the United States in an unfavourable light, regardless of Indonesia's own strategic interests in developing close cooperation with the United States. ${ }^{11}$

more recent publications are Effendy (2003) and Mietzner (2009).

10 Indonesia hosted the first Asia-Africa conference in Bandung in 1955, which was the first such gathering of its kind, bringing the newly independent countries of Africa and Asia together to express their determination to oppose all forms of colonialism and to chart a peaceful coexistence in the bipolar world of the Cold War. This Bandung conference was generally viewed as an antecedent for the Non-Aligned Movement, established in Belgrade in 1961, in which the members stated their determination to follow an independent course rather than being forced to choose between the two superpower blocs in the Cold War.

11 For a comprehensive discussion on this subject see Sukma (2003) and Perwita (2007). 
Lately, however, the issue of the Iranian nuclear programme has also become an 'Islamic' issue in Indonesia because US-led sanctions against Iran, which is suspected of trying to develop nuclear weapons capability, are seen by many Indonesians, including a large number of legislators, as unfairly targeting a Muslim country, while the United States has turned a blind eye to Israel's undoubted nuclear weapons development. The argument that Iran as a member of the Non-Proliferation Treaty (NPT) is suspected of violating its NPT commitment, but Israel is not a party to the NPT and is, therefore, not bound by it, carries little weight among these politicians and the general public. When Indonesia in 2007, as a non-permanent member of the United Nations Security Council (UNSC), voted in favour of UNSC Resolution 1747 to impose sanctions on Iran for its suspected NPT non-compliance by continuing to enrich uranium, the DPR voted overwhelmingly to have an interpellation on the Iran Resolution. The DPR insisted on summoning the President to the DPR to explain Indonesia's support for the UNSC Resolution on Iran and when Yudhoyono sent only his ministers to the DPR, there were several weeks of stand-off between the DPR and the government as the DPR refused to meet the ministers. ${ }^{12}$ The Indonesian government, while mindful of domestic Muslim pressure to refrain from agreeing UNSC resolutions sanctioning Iran or establishing diplomatic relations with Israel, does not colour its foreign policy in any substantively "Islamic" manner.

Under Soeharto's New Order, Indonesia's foreign policy was primarily aimed at promoting regional peace and stability through regional cooperation and at mobilising financial assistance from the major developed countries, both policies deemed critical for Indonesia's economic development. Indonesia, therefore, put priority on its relations with the ASEAN countries and a few industrialised countries, notably the United States, Japan and a number of West European nations. In contrast, Islamic countries were kept at arm's length, particularly after the 1979 Islamic Revolution in Iran, because the Soeharto government was afraid of the influence that radical Islamic ideas might have on

12 http://www.antara.co.id/print/?i=1181017169 
Indonesian Muslims. It is important to note that Indonesia refused to sign the charter and become a full member of the Organisation of the Islamic Conference (OIC) when it was established in 1972, on the grounds that Indonesia is not an Islamic state. Notwithstanding its strong support for the struggle of the Palestinians, Indonesia initially refused to allow the Palestine Liberation Organisation (PLO) to set up an office in Jakarta in 1974. Indonesia's policy towards the Islamic world only began to change in the late 1980s, when President Soeharto began to court Muslim groups in Indonesia to shore up his political base during the later years of his rule. ${ }^{13}$ The PLO was allowed to open its representative office in 1989 and Indonesia began to pay more attention to Islamic countries, including becoming a full member of the OIC. Nevertheless, this new foreign policy initiative was more an effort to find alternative markets for Indonesian exports than a reflection of Indonesia's interest in promoting Islamic solidarity as such.

\section{Challenges Ahead}

The questions are therefore whether Indonesia will be able to rise to the challenge of its own current national aspirations and international expectations, so that its status as the world's third largest democracy and the largest Muslim nation can be used as a lever in its foreign policy, either in promoting Indonesia's national interests, in mediating international conflicts where Muslim interests are involved, or in providing an alternative model of a modern Islamic society. The fact of the matter is, as a result of the relative neglect of the Islamic world in the past despite Indonesia's status as the largest Muslim nation, Indonesia's position in the OIC has so far been quite marginal. Furthermore, many Arab countries tend to look down on Indonesia's Islamic credentials, pointing out that Islam in Indonesia is not quite what it should be. More thought and effort is clearly needed before Indonesia can put

13 Soeharto supported the establishment of ICMI (Ikatan Cendikiawan Muslim se-Indonesia [Association of Indonesian Muslim Intellectuals]) in 1991, led by then Minister of Science and Technology, BJ Habibie, regarded as a protégé of Soeharto and who was later in 1998 selected as vice-president by Soeharto. 
substance to, and act upon, the idea already put in place by President Yudhoyono concerning Indonesia's international identity and its union of democracy, Islam and modernity. These efforts should be directed at convincing the outside world by packaging this new identity as part of a public relations exercise to improve Indonesia's international image and standing. Even more important, further homework needs to be done domestically so that the image will match the reality.

To some extent, current domestic political conditions and the international climate favour Indonesia improving its relations with Islamic countries in the Middle East on particular issues. The constraint that had existed during most of the New Order period has largely disappeared, for Indonesia seems to have more or less settled the question of relations between Islam and the state, at least at the national level. Indonesia is not, and is unlikely to become, an Islamic state, but political Islam has again found its voice and taken an active part in Indonesia's democratic transition. The entry of Islamic voices into the political mainstream has naturally also had an effect on Indonesia's foreign policy because there are now greater demands for Indonesia to pay more attention to its relations with the Islamic world, particularly with Middle Eastern countries.

It is important to note, however, that this greater interest in improving relations with Islamic countries has more to do with expected economic gains than with the issue of Islam as a common faith and the problems it faces in today's globalising world. One of the criticisms of Indonesia's foreign policy in the past was that it had not been able to forge closer economic links with the oil-rich states in the Middle East and benefit from their huge reserves of petrodollars. In this respect, Indonesia is lagging behind Malaysia. Arguments have been put forward that Indonesia should be able to capitalise more on its Islamic credentials to improve its ties with countries in the Middle East and get them to invest in Indonesia. On 25 April 2006, President Yudhoyono embarked on a ten-day visit to five Arab states, namely, Saudi Arabia, Kuwait, Qatar, United Arab Emirates and Jordan, accompanied by an entourage of 150 people, mostly businessmen, to do precisely what some had 
suggested. ${ }^{14}$ Indonesia needs huge inflows of foreign capital to finance its economic development, particularly its major infrastructure projects, and many of the Arab states need an alternative place to invest their money, particularly after the difficulties they encountered in the wake of the 2001 terrorist attacks in the United States.

Indonesia's aspirations to play a more active role in helping to defuse the Palestinian-Israeli crisis, which would also contribute to improving Indonesia's international standing, have possibilities as well as limitations. On the one hand, Indonesia has been approached by a number of Western countries, including the United States, to approach the new Hamas government and persuade it to moderate its stance, while the Palestinians have asked Indonesia to intercede with Western donor countries on their behalf so that they would not cut off funding to Palestine after the formation of the Hamas-led government. At the urging of President Mahmoud Abbas, who made a state visit to Jakarta, President Susilo Bambang Yudhoyono also participated in the Annapolis meeting, which was hosted by US President George W Bush in November 2007, to discuss the Israeli-Palestinian issue. ${ }^{15}$ On the other hand, Indonesia's ability to play a mediating role in the Palestinian-Israeli conflict is constrained by the fact that it does not have diplomatic relations with Israel. As mentioned earlier, there is very strong domestic opposition, particularly from the Islamic groups, to any suggestions that Jakarta should recognise Israel before the Palestinian state is established. Even informal contacts between representatives of the Indonesian government and Israel invite strong criticisms from Indonesia's Islamic groups. The promise of full diplomatic recognition from the world's largest Muslim nation is seen to be the only real leverage that Indonesia has over Israel.

The challenge for Indonesia is not in the instrumental use of Islam in its foreign policy, which is fairly easy once the domestic political situation

14 http://www.presidenri.go.id/index.php/fokus/2006/04/25/449.html

15 'Transkripsi Press Briefing Menlu RI Hassan Wirajuda mengenai Persiapan Keikutsertaan Indonesia dalam Konferensi di Annapolis'. Jakarta, 23 November 2007. http://www.deplu. go.id/Pages/SpeechTranscriptionDisplay.aspx?Name1=Transkripsi\&Name2=Menteri\&ID $\mathrm{P}=192 \& \mathrm{l}=\mathrm{en}$ 
makes it possible. The real challenge is in substantiating the claim that, in Indonesia, democracy, Islam and modernity truly go hand in hand, and going on from this to establish an effective foreign policy that can have influence in the current global discourse between Islam and the West and within the Islamic world itself. For this to happen Indonesia first needs to demonstrate a record of success in transforming its society into one in which Islamic values and practices directly contribute to the consolidation of democracy and the preservation of a tolerant pluralism which is open to the outside world and embraces modernity. It is important to emphasise that democracy does not stop at elections or entail the imposition of the will of the majority on the rest of the population. Although the population of Indonesia is predominantly Muslim, respect for religious minorities, who enjoy equal rights under the Constitution in every aspect, must be one of the main characteristics of Indonesian national identity. Acts of intolerance against religious minorities, as well as passing laws that discriminate against women or eliminate cultural diversity are clearly contrary to the spirit of this national identity. The teachings of Islam should not primarily be used to regulate private morality in public places, but rather to inject a greater sense of a public morality of honesty, integrity and accountability in a country long mired in corruption. Islam is also noted for its concerns for the poor and the weak and its strong opposition to injustice and oppression, and as such Indonesia's public policy should reflect this overall concern for justice and freedom in the national and international contexts.

As foreign policy is an extension of domestic policy, the values and principles that are held dear by a nation may be expected to inform its foreign policy formulation and implementation as well, within the boundaries of acceptable international practices. It is, therefore, to be hoped that Indonesia's foreign policy will not simply be used as an instrument for satisfying its national interests or immediate strategic and material needs, but also be used to promote such universal values as democracy, tolerance and mutual respect world wide. 
The most challenging task for Indonesia, however, is to establish its claim as an alternative form of Islamic society within the Islamic world. Today when people talk about Islam, the reference point is almost always the Middle East. Despite the fact that there are more Muslims living in Southeast Asia than in the Middle East, Southeast Asian Muslims have remained peripheral in Islamic affairs. Indonesia's success in maintaining national unity, consolidating democracy and developing its economy and human resources would undoubtedly attract the attention of other developing countries, including Muslim countries in the Middle East. All of these achievements, however, will not be sufficient in informing discourse within the Islamic world concerning the proper role of Islam in society, the relations of Islam and the state or the response of Islam to the challenges of globalisation. Unlike in secular Western traditions where religion and the state are now separate, though such a separation has only been achieved through successive wars not many centuries ago, in Islam such a complete separation is unknown and, to many Muslims, unacceptable. Although in the West modernity has brought secularism, in most Islamic countries, including Indonesia, modernity has been accompanied by greater religiosity. Indonesia's democratic transition takes place amidst an Islamic revival.

What is needed now is for Indonesian scholars of Islam and political science to produce authoritative writings on the empirical experience of the relations between democracy, modernity and Islam in Indonesia, and from there to construct a theoretical and conceptual framework about an alternative model of Islam and society in this global era. Such writings should not only be published in the Indonesian language, but must also be made available in English and Arabic so that they can enrich the currently available international literature on Islam. Backed by such intellectual input, it is hoped that Indonesia's foreign policy will be able to engage more fruitfully in the battle of ideas taking place between Islam and the West and within the Islamic world itself. Only then can Indonesia position itself as a bridge between the Islamic world and the West and as a possible reference point for other Muslim countries that may wish to emulate Indonesia's experience. 


\section{References}

Anwar, Dewi Fortuna. (1991). Indonesia in ASEAN. Foreign policy and regionalism. Singapore: Institute of Southeast Asian Studies.

Effendy, Bachtiar. (2003). Islam and the state in Indonesia. Singapore: Institute of Southeast Asian Studies.

Feith, Herbert. (1962). The decline of constitutional democracy in Indonesia. Ithaca: Cornell University Press.

Mietzner, Marcus. (2009). Military politics, Islam and the state in Indonesia: from turbulent transition to democratic consolidation. Singapore: Institute of Southeast Asian Studies.

Noor, Firman. (2010). 'Secercah Harapan bagi Pendewasaan Politik Bangsa'. Seputar Indonesia, 10 March 2010.

Perwita, Anak Agung Banyu. (2007). Indonesia and the Muslim world. Islam and secularism in the foreign policy of Soeharto and beyond. NIAS Report.

Sukma, Rizal.(1995). 'The evolution of Indonesia's foreign policy: an Indonesian view'. Asian Survey, 35 (3): 304-315; URL: http://www.jstor.org/stable/2645547 Accessed: 10/03/2010 00:53.

------. (2003). Islam in Indonesian foreign policy. London and New York: RoutledgeCurzon.

(2010). 'Insight: Debating Indonesia’s Global Role'. Jakarta Post. Thursday, 11 March 2010.

Weinstein, Franklin B. (1976). Indonesian foreign policy and the dilemma of dependence. Ithaca: Cornell University Press.

Wirajuda, Hassan. (2007). 'Transkripsi Press Briefing Menlu RI mengenai Persiapan Keikutsertaan Indonesia dalam Konferensi di Annapolis'. Jakarta, 23 November 2007.

Yudhoyono, Susilo Bambang. (2005). Speech before the Indonesian Council on World Affairs (ICWA). Jakarta, 20 May 2005. 